\title{
How Wages Change: Micro Evidence from the International Wage Flexibility Project
}

\author{
William T. Dickens, Lorenz Goette, Erica L. \\ Groshen, Steinar Holden, Julian Messina, Mark E. \\ Schweitzer, Jarkko Turunen, and Melanie E. Ward
}

W orkers' wages are not set in a spot market. Instead, the wages of most workers-at least those who do not switch jobs-typically change only annually and are mediated by a complex set of institutions and factors such as contracts, unions, standards of fairness, minimum wage policy, transfers of risk, and incomplete information. The goal of the International Wage Flexibility Project (IWFP) - a consortium of over 40 researchers with access to individual workers' earnings data for 16 countries-is to provide new microeconomic evidence on how wages change for continuing workers. Wage changes due to worker mobility are governed by different processes and are beyond the scope of this study.

A key question in the theoretical and empirical literature, as reviewed in

- William Dickens is Senior Fellow in Economic Studies, The Brookings Institution, Washington, D.C. Lorenz Goette is Assistant Professor, University of Zurich, Zurich, Switzerland. Erica L. Groshen is Vice President and Economist, Federal Reserve Bank of New York, New York City, New York, and Research Fellow, Institute for the Study of Labor (IZA), Bonn, Germany. Steinar Holden is a Professor of Economics, University of Oslo, Oslo, Norway, and a Research Fellow, Center for Economic Studies-Information and Forschung Institute (CESifo), Munich, Germany. Julian Messina is Economist, European Central Bank, Frankfurt, Germany, Assistant Professor, Universitat de Girona and Research Fellow, Centre for Studies in Economics and Finance (CSEF), Università di Salerno, Italy. Mark Schweitzer is Assistant Vice President and Economist, Federal Reserve Bank of Cleveland, Cleveland, Ohio. Jarkko Turunen is Economist with the European Central Bank, Frankfurt, Germany. Melanie Ward is Senior Economist, European Central Bank, Frankfurt, Germany, and Research Fellow, Institute for the Study of Labor (IZA), Bonn, Germany. Their e-mail

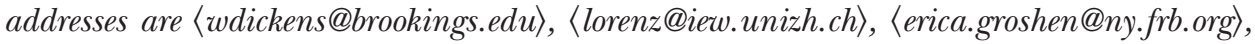

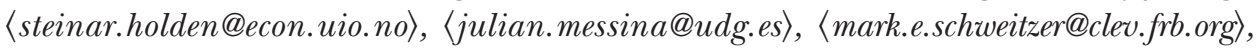
$\langle j a r k k$.turunen@ecb.int $\rangle$, and $\langle$ melanie.ward-warmedinger@ecb.int $\rangle$, respectively. 
Camba-Mendez, García, and Rodríquez Palenzuela (2003) and Holden (2004), is the extent to which job stayers resist wage cuts-that is, the extent to which downward wage rigidity exists. These studies have yielded remarkably inconsistent findings, both across different countries and across different datasets for the same country. For example, in U.S. data, studies using company wage records typically show almost no wage cuts, while several papers analyzing individual data from the Panel Study of Income Dynamics (PSID) find what appear to be many nominal wage cuts. (Those studies take no account of measurement error-for discussion, see Akerlof, Dickens, and Perry, 1996; Altonji and Devereux, 2000.) However, studies of individual earnings data from Great Britain show less evidence of downward nominal wage rigidity than what is discerned from analysis of U.S. data (Nickell and Quintini, 2003; Smith, 2000). Moreover, almost all of the existing studies concentrate on nominal wage rigidity, even though workers may resist real wage cuts as well as nominal wage cuts.

The International Wage Flexibility Project sought to reconcile these divergent results. The goals of the project were to gather international data on wages that make it possible to describe the extent of wage flexibility, with a particular focus on the extent of downward wage rigidity, and then to determine how measures of wage flexibility are affected by the wage-setting regimes that typically vary by country and by the different types of data on wages. This paper reports on our analyses of individuals' earnings changes in 31 different datasets from which we obtain a total of 360 wage change distributions-one for each year in each dataset. These data were analyzed by 13 research teams from participating countries and a coordinating team based at the European Central Bank, the Federal Reserve Banks of New York and Cleveland, the Brookings Institution, and the Universities of Oslo and Zurich.

Like previous studies, we find a remarkable amount of variation in percentage wage changes across individuals in nearly every country in every year. We estimate that the standard deviation of annual wage changes within countries averages at least 7.7 percentage points, although this measure contains some uncertainty due to the extent of measurement error. Wage changes in nearly every country in every year have a notably nonnormal distribution. Workers' wage changes are both much more clustered around the median and have many more extreme values than the normal distribution. Moreover, nearly all countries show asymmetry in their wage change distributions. One common asymmetry is a high incidence of wage freezes and a lack of nominal wage cuts, which we take as evidence of downward rigidity in nominal wages. A second asymmetry is a tendency for workers' wage changes to clump in the vicinity of the expected rate of price inflation, which we take as evidence of downward real wage rigidity. We find evidence of substantial variation across countries in the extent of both downward nominal and downward real wage rigidity, even after we control for dataset characteristics. When we examine how our measures of rigidity relate to a number of characteristics of labor markets in the countries of our sample, only greater union density appears to have a robust 
relationship with downward real wage rigidity — that is, countries with greater union density have a greater incidence of downward real wage rigidity.

\section{International Data on Wage Changes}

The 31 datasets analyzed for the International Wage Flexibility Project cover over 31 million wage changes and are diverse with respect to source, coverage, years, and definitions of variables of interest. An important advantage of studying many different datasets is that we can consider how various dataset characteristics can cause observed differences in wage rigidity across countries.

Table 1 describes the data sources. The three main sources of data are employment registers, household surveys, and employer surveys. An employment register, which is maintained by a government for the administration of taxes and/or benefits, covers all workers in a specified universe and has minimal reporting error. Some country teams worked with random samples drawn from the registers, while others analyzed the entire census. Household surveys sample from the universe of all workers, but typically rely on respondent recall and so are subject to both sampling and reporting error. Employer wage and salary surveys typically cover all workers in the occupations and firms in their purview and draw their data from payroll records, but vary considerably in how many occupations or firms they cover. The employer surveys in the International Wage Flexibility Project are particularly comprehensive because they are conducted by national employer associations and are used extensively for policy and managerial purposes.

The time periods covered by the different datasets vary, with some starting in the early 1970s and some running through the beginnings of the 2000s, with an average of twelve years per dataset. The total 360 dataset years observed include multiple datasets for twelve countries: Austria, Belgium, Denmark, Finland, France, Germany, Italy, Norway, Portugal, Sweden, Switzerland, and the United Kingdom.

Datasets also vary in terms of the compensation measure available. In each dataset, we attempt to measure the wage component of compensation only. Ideally we would analyze the agreed-upon hourly, weekly, monthly, or annual compensation rate for workers in each of our samples. This measure would include not just monetary compensation, but also the value to the worker of all nonpecuniary compensation as well. We do not view total compensation cost to employers as a good proxy for this concept, because it can be affected by price adjustments in components such as workers' compensation insurance or employment taxes, without a change in the effective compensation that the worker sees. Focusing on the wage component avoids this problem of shifting costs and has the additional benefit of being the most consistent concept across countries. Focusing on wages does have the drawback of omitting consideration of other aspects of compensation that may be deliberately adjusted by employers to increase flexibility. However, some evidence suggests that these other adjustments may not have much effect on downward wage rigidity: for example, Lebow, Saks, and Wilson (2003) find no 


\section{Table 1}

\section{International Wage Flexibility Project Dataset Characteristics}

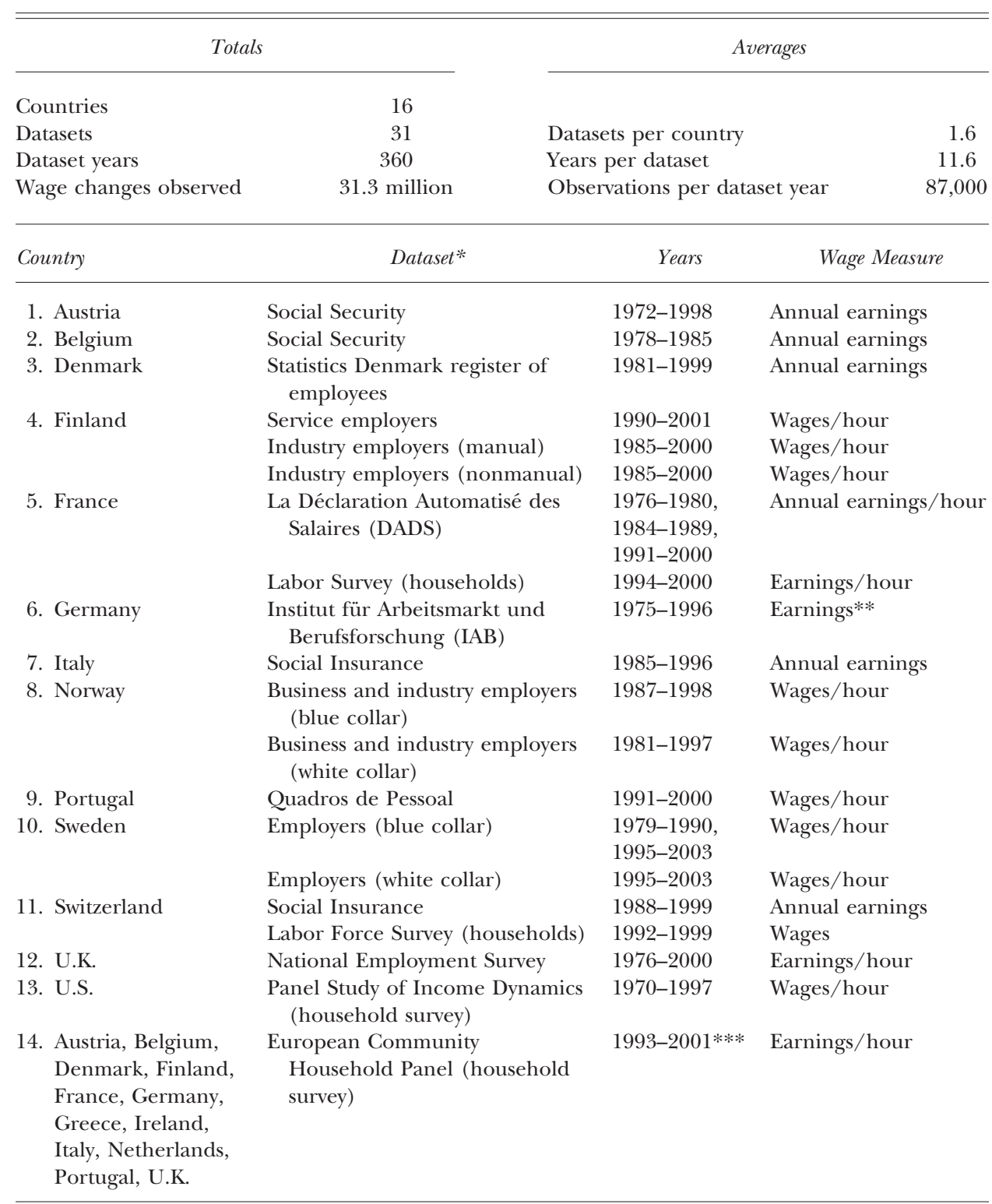

* Datasets come from employer surveys, labor force surveys, and administrative sources. Datasets not labeled "employers" or "surveys" are from administrative sources.

** German wage data refer to earnings for most of the time period, but to wages before 1984 .

**** Available years vary somewhat by country.

evidence that U.S. employers change other types of remuneration so as to circumvent the binding downward rigidity of base wages. Finally, we exclude large outliers in wage changes because they likely reflect wage reporting errors or unidentified 
job changes, rather than the actual experience of ongoing workers. Increases of more than 60 percent in wage data or 100 percent in annual income data and cuts of more than 35 percent in wage data or 85 percent in income data were eliminated.

Eleven of our 31 datasets have either information on workers' hourly wages, or measures of their base earnings over fixed periods of time that are equivalent to hourly wage data for our purposes. In the other cases, we have monthly or annual income data that must be converted to hourly wages using hours data (usually the normal hours of work). Since hours measures are often imprecise for a number of reasons, this procedure introduces error into our wage measure akin to those in survey data. We construct our measure of annual percentage wage changes by taking the difference between consecutive years' log reported or computed wages.

As noted earlier, we restrict our analysis to job stayers so that we can concentrate on the wage rigidity in ongoing employment relationships. In our data, restricting attention to job stayers typically reduces our samples by about 17 percent.

\section{How Wage Changes Are Distributed}

To illustrate some key features of wage change distributions, Figure 1 shows the actual distribution of changes in log wages (represented as percentage changes in levels) received by wage earners who were heads of households in the United States in 1987, by white-collar workers in Finland in 1988, by all workers in the United Kingdom in 1984, and by all workers in Ireland in 1996. The histograms are constructed using intervals that are 1 percentage point wide, so that the height of the rectangles shows the fraction of people with wage changes in that range. In addition, the fraction of workers with no change in their pay is shown with the dark bar at zero. ${ }^{1}$

A number of key features typical of wage change distributions are illustrated in these four panels. First, all four examples show considerable variation across workers in the magnitude of wage changes within a year. The average standard deviation of measured percentage wage changes across all our datasets is 9 percentage points. Second, median wage changes typically (in 80 percent of datasetyear observations) exceed contemporary or lagged inflation rates (shown in black lines). This pattern is expected when productivity is growing and labor market slack is not excessive.

Third, wage changes are not normally distributed. Given the median and variance actually observed, people's wage changes are much more clustered and

\footnotetext{
${ }^{1}$ The cells on either side of zero are slightly less than 1 percentage point wide as the cell at zero includes observations within 0.017 percentage points of zero $(0.1$ percentage points in countries where wages are constructed from annual income) and those observations are not included in the cells on either side. We did this because problems in the accuracy with which earnings and hours data were recorded in some datasets created tiny phantom wage changes.
} 
Figure 1

\section{Wage Change Histograms}
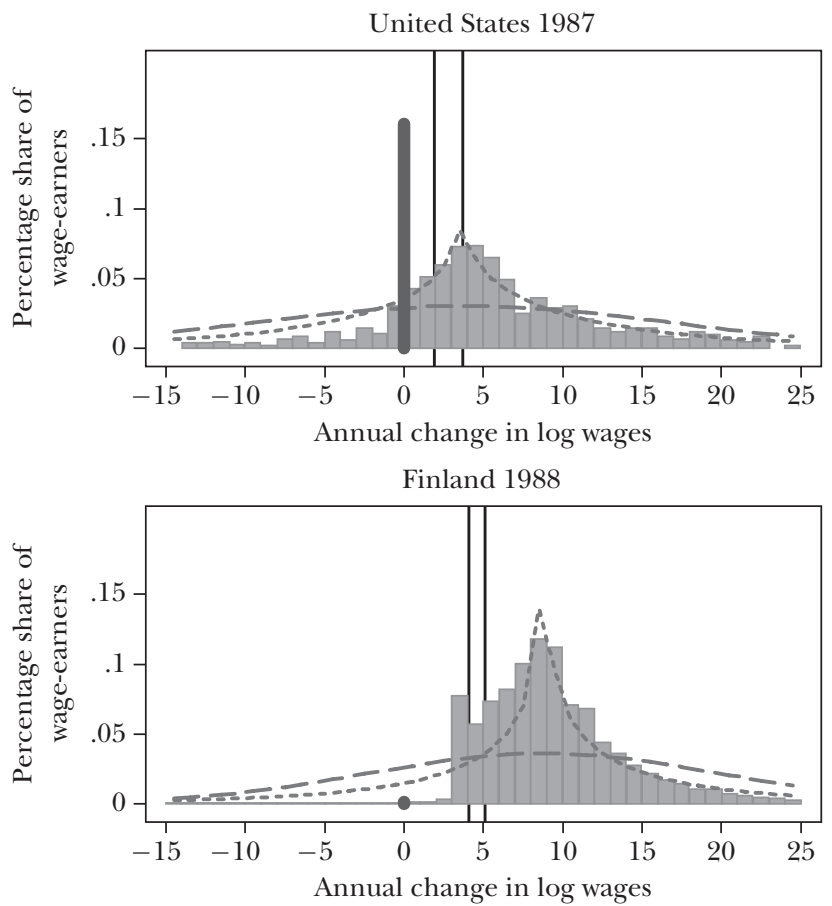

United Kingdom 1984
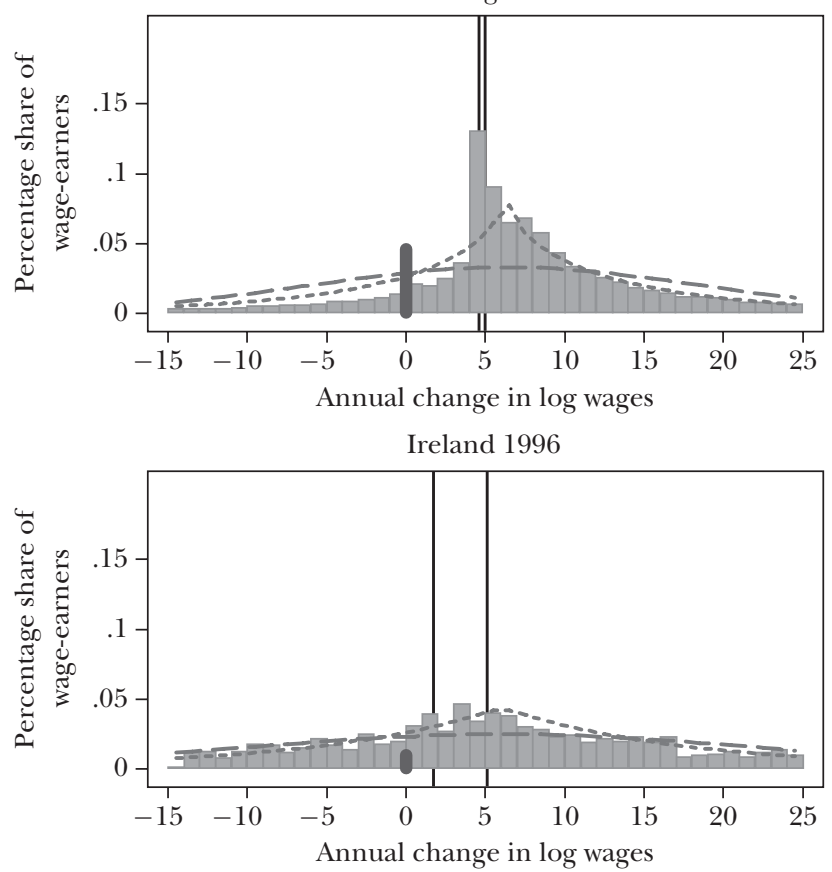

$\equiv$ - Weibull distribution ---- Normal distribution Zero spike $\overline{\bar{\nu} m}$ vertical lines indicate contemporaneous and prior year's inflation. 
peaked around the median change than in a normal distribution. Also, the wage change distributions have many more extremely high raises than would occur in a normal distribution. (This is not apparent on Figure 1 as the far tails are not graphed.) A lesser-known statistical distribution called a Weibull distribution does fit to the upper tail of each wage distribution (that is, the area above the median) much better than does the normal distribution. When a variable has a Weibull distribution, the density declines exponentially in the log of the distance from the mode.

For wage changes below the median value (the lower tail), only for Ireland does the Weibull distribution fit the data particularly well. The Irish wage changes do not display two features found in other distributions. The Irish workers have a lower incidence of wage freezes (the spike at zero) than do the U.S. and U.K. workers; indeed, Irish workers reported almost as many nominal wage cuts as would be expected with a symmetric distribution. In addition, the Irish workers' wage changes were not as strongly clustered near the inflation rate (either current or last year's rate), as were the U.K. and Finnish workers' wage adjustments. One main reason why the Irish distribution of wages has higher variance and is less smooth than the other distributions is because of the data source. The Irish data reported here are from the European Community Household Panel, a dataset with fewer observations and more reporting error than most of our other datasets.

Figure 2 shows broader evidence based on all our wage data, of two key asymmetries: one is nominal wage freezes, while the other is the clustering of wages around the level that would represent a real wage freeze. For these figures, we include all dataset years with the exception of those datasets reporting annual income data, because the categories used to classify observations are not the same as those used in the analysis of the other datasets. This leaves us with 273 dataset years.

Figure 2 a shows the asymmetry caused by downward nominal wage rigidity. In this figure, we average the frequency of workers in each wage change cell across datasets. On average, about 8 percent of workers receive nominal wage freezes in the wage samples. This may not seem like much, but recall that in many years, many of the countries covered were experiencing considerable inflation. Figure $2 \mathrm{a}$ also shows that the distribution of wages is not symmetric; besides the spike at zero there are fewer observations below zero than symmetry with the upper half of the distribution would lead one to expect.

Figure 2a does not indicate the extent of downward real wage rigidity, since rates of actual and expected inflation vary across countries and years. To do this, we can instead center the wage change distribution for each country and year on the interval that contains its median wage change, as shown in Figure 2b. We also drop the nominal wage freezes seen in Figure 2a. Hence, the height of each bar shows the average share of workers receiving a wage change of the specified amount above or below the median change in that year (providing the worker did not have a nominal wage freeze). We expect that, averaged over the business cycle, wage growth equals price inflation plus productivity growth. Sixty-one percent of contemporaneous inflation rates fall in the histogram cell containing the median or 
Figure 2

Wage Change Distribution for All Countries and Years

Figure 2a: Nominal Wage Change

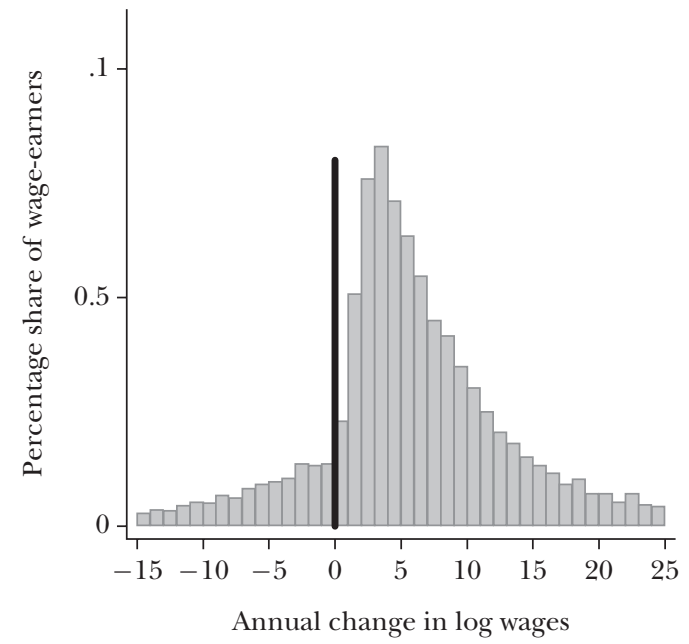

Figure 2b: Wage Change Centered on Median

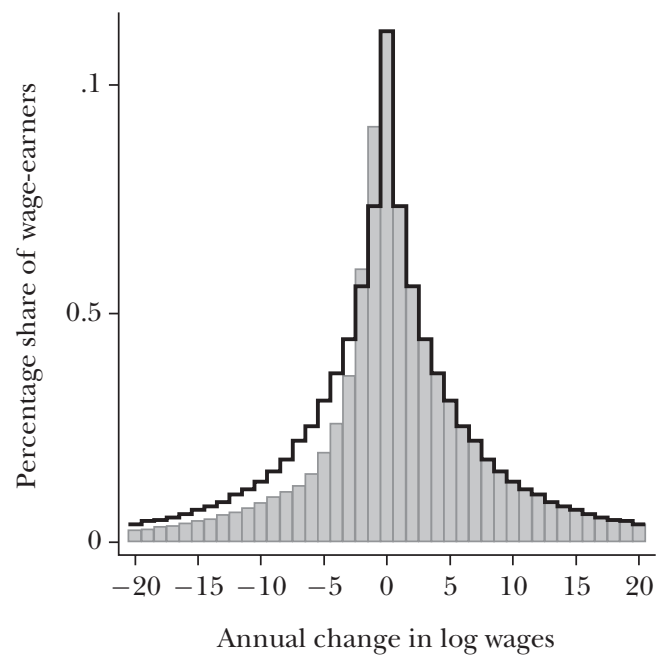

Note: To make it easy to see what symmetry would imply for the distribution, in Figure $2 \mathrm{~b}$ we have superimposed the outline of the upper half of the distribution on the lower half of the distribution.

the in two cells just below it, and 51 percent of the previous years' inflation rates fall in that range. Thus the raises of workers with expected real wage freezes will be clustered a percentage point or two below the median wage change.

To make it easy to see what symmetry would imply for the distribution in Figure $2 b$, we have superimposed the outline of the upper half of the distribution on the lower half of the distribution. The incidence of wage changes in the lower 
tail is substantially lower than in the symmetric distribution, with the exception of the two cells just below the median, where the incidence of wage changes is higher than the symmetric distribution. This suggests that many wage change observations have been affected by downward real wage rigidity, which has pushed these low wage changes up from the left of the lower tail towards the bins closer to the median. Thus, across these national samples, many more workers experience wage increases close to the expected rate of inflation than symmetry would imply, and many fewer receive wages changes below that level.

Recall that not all countries show signs of downward real rigidity; thus, this divergence from symmetry is all the more notable because it is driven only by a subset of countries. Furthermore, if we add the wage freezes back in, distributing them proportionally over the lower tail with the missing observations, the asymmetry is still notable.

Clearly, the dispersion of wage changes is different above and below the median. We calculated a measure of standard deviation separately for the portion of the distribution above the median and for the portion below the median for all the IWFP datasets. ${ }^{2}$ This measure for the lower is smaller than the measure for the upper tail both on average-7.4 percent versus 13 percent-and in almost every case (356 out of 360 IWFP dataset years). ${ }^{3}$ The difference in dispersion between the upper and lower tail is driven mainly by the two sources of asymmetry we just described. A closer examination reveals that the difference between the dispersion of the upper and lower tail declines as wage inflation increases. This pattern seems to be due to the lower incidence of wage freezes as the median wage change moves further away from zero.

Finally, we can learn about errors in wage data from the auto-covariance of individual wage changes. We are computing wage changes from wage levels reported a year apart. Thus, the presence of errors in the reporting, recording, or calculating of the wage level in any year-assuming that errors are not correlated from one year to the next-would cause large positive wage changes to be followed by small or negative wage changes in the next year, while small positive changes, or any size negative changes, would be followed by large positive changes. All else equal, the more errors present in a particular dataset, the more negative will be the auto-covariance of wage changes. We have computed the auto-covariance of wage changes for every year and dataset in our study excluding the datasets where the wage measure is based on annual income. ${ }^{4}$ Nearly all (91 percent) of the datasetyear auto-covariances are negative, with an average value of -0.002 . Negative auto-covariance could also be a feature of the true wage change distribution.

\footnotetext{
${ }^{2}$ Specifically, we calculated the square root of the mean squared deviation of observations from the median and carried out this calculation separately for the upper and the lower tail.

${ }^{3}$ The exceptions are France in 1980 and 1994, Italy in 1991, and Switzerland in 1999.

${ }^{4}$ If the dates over which income are measured are not synchronized with wage changes, the income measure will confound two wage levels. This induces a positive correlation in wage changes on top of the negative correlation caused by errors and makes the income data inappropriate for this exercise.
} 
However, in the few datasets where base wages are reported in administrative data, cases where we would expect the fewest errors, the auto-covariance is essentially zero. The fact the auto-covariance is absent in data with no errors strongly suggests that measurement error is the source of virtually all auto-covariance that we do observe in our wage-change data. If the only source of auto-covariance in our data is measurement error, and the measurement errors are uncorrelated from one period to the next, then the average standard deviation of measurement error in the data is about 4 percentage points. This would imply that the average standard deviation of true wage changes is about 7.7 percentage points across our datasets. ${ }^{5}$

\section{What Statistical Distributions Imply about Wage Setting}

The features of the wage change distributions highlighted above-their tendency to follow a Weibull distribution above the median, with higher peaks at the median value and more frequent high positive values compared to the normal distribution, along with the evidence of nominal and real asymmetries-may reveal quite a bit about the wage-setting process. The central limit theorem states that a variable will tend to be normally distributed when a large number of independent influences affect it in an additive manner. In more practical terms, suppose each worker's performance was scored separately for a number of independent tasks or competencies that comprised a job. Then, suppose that the wage increases for the workers are based on additive rewards for the number of independent successes a worker has, compared to average performance. In such a setting, wage changes should be approximately normally distributed. However, the evidence shows that wages are not normally distributed, but instead have more observations at their peak and in their tails than a normal distribution.

A Weibull distribution will provide a good approximation to the distribution if, instead, workers' raises are based on sequential standards, where only those who meet all prior standards are considered for the next level, and at each level, rewards increase exponentially. For example, assume that workers' abilities are tested in a prescribed sequence and at each stage the surviving workers either fail and drop out of further contention or "make the grade" and go on to compete in the next round. ${ }^{6}$

People of only average performance receive the median wage changes. Those who achieve one level of distinction (but no more) receive a small bonus of size $b$ above the median wage change. From among those who succeed the first time,

\footnotetext{
${ }^{5}$ Under the assumptions just specified, the auto-covariance will equal minus the variance of the measurement error. Thus, adding it to the variance of wages in our datasets yields an estimate of the true variance of wage changes, and taking the square root of that yields the true standard deviation of wage changes. We average this value across all countries (except those where wages are based on annual earnings, which have a more complicated covariance structure) and years to get 7.7 percentage points. ${ }^{6}$ While this section uses individual performance to describe a process that generates a Weibull distribution, this process could also work among "surviving" teams, establishments, or firms.
} 
some will achieve just one more level of distinction and receive an increase of $b 2^{a}$ $(a<1)$. Others will manage to distinguish themselves even further (a third time) and receive a bonus of size $b 3^{a}$. If a constant fraction of workers fails to reach each successive level of distinction, then the distribution of wage increases will be approximated by a Weibull distribution. ${ }^{7}$

The relatively good fit of the Weibull distribution to the upper tail suggests that a survivor process like this may be at work determining wage increases. The process just described is similar in some ways to Rosen's (1986) tournament model; though that model was meant to describe the distribution of wages and changes over a career rather than a single year. It also doesn't explain the pattern in the lower tail of the distribution, which is more varied. If there are few wage freezes, in either real or nominal terms - as we see in the case of Ireland in 1996 in Figure 1-it appears that wage changes lower than the median are determined by a similar process to wage increases. That is, cascades of shortcomings lead to deviations from the average that increase at an exponential rate with more failures.

However, labor markets in many countries do display a degree of downward wage rigidity. The presence of downward nominal wage rigidity can explain the presence of large numbers of wage freezes-that is, the spike at zero-and the relative lack of wage cuts. Downward real wage rigidity can account for the tendency for a larger number of workers to receive wage changes closer to the expected rate of inflation than might be expected if symmetry were preserved. That would also explain the paucity of observations below this range in the lower tail. Finally, the presence of both downward nominal and real wage rigidity would explain the tendency for the variance of the lower tail to be less than the variance of the upper tail, while the presence of downward nominal wage rigidity would explain why the difference declines as the rate of wage inflation rises.

\section{Measuring Rigidity}

We can use the observed deviations from symmetry in the wage change distributions to construct, for each distribution, measures of the extent of downward

${ }^{7}$ In this example, the Weibull cumulative distribution function would take the form

$$
W(x)=1-e^{-p\left(\frac{X}{b}\right)^{1 / a}}
$$

where $p$ is the fraction of workers at each level of distinction who fail in rising to each higher level of distinction. The Weibull cumulative distribution function that we use to describe the distribution of wage changes above the median can be viewed as an exponential distribution where the argument of the distribution has been scaled by taking it to a power between 0 and 1 . Exponential distributions provide a much better fit to wage changes above the median in our wage change distributions than do normal distributions. However, the Weibull allows an even better fit. Actual wage changes are both more clustered and have more extremely large raises and wage cuts than predicted by exponential distributions. 
nominal and downward real wage rigidity. In conceptual terms, we are seeking measures that are largely independent of the dataset-year economic conditions in the various countries. Thus, we do not want a measure such as the fraction of workers with nominal wage freezes in a year, because this fraction varies with the expected rate of inflation and so could prove a misleading basis for thinking about the extent of wage rigidity. Instead, we construct measures that represent the fraction of workers "covered by" each type of wage rigidity. In most cases this "coverage" is informal, not contractual. An alternative term would be "susceptible to" rigidity. However, wage rigidities are likely to reflect worker resistance to wage cuts, and we think of workers whose wages are rigid as being "covered" by some implicit or explicit agreement or norm that limits their employers' ability to cut their wages.

We call our measures of downward nominal and downward real wage rigidity $n$ and $r$, respectively. Each is conceived of as the fraction of workers who, if they are in the position of being scheduled for either a nominal or real wage cut, whether because of individual performance or external conditions, would receive a nominal or real wage freeze instead.

For downward nominal wage rigidity, our measure is straightforward. We assume that everyone who had a nominal wage freeze would have had a nominal wage cut in the absence of downward nominal rigidity and construct

$$
n=f_{n} /\left(f_{n}+c_{n}\right),
$$

where $f_{n}$ is the fraction of workers with nominal wage freezes and $c_{n}$ is the fraction with nominal wage cuts. ${ }^{8}$

Our estimate of downward real wage rigidity is conceptually similar, but for several reasons more complicated in practice. First, because inflation expectations can differ between firms and individuals, there is no sharp spike in the distribution where we can confidently say that everyone at that spike experiences a real wage freeze. Thus, our measure of downward real wage rigidity is based on the fraction of observations missing from the lower tail below our estimate of the expected rate of inflation, as compared to the equivalent area of the upper tail of the distribution. ${ }^{9}$ The underlying idea is that in the absence of downward real wage rigidity, there would be as many people in the lower tail as in the corresponding region of the upper tail, but that downward real wage rigidity causes some of those who would be in the lower tail to be piled up around the expected rate of inflation.

\footnotetext{
${ }^{8}$ Although we allow for wage changes slightly more or less than zero to be in the zero bin to compensate for some numerical accuracy problems in the data we are using, we are confident that the zero wage changes are overwhelmingly exact wage freezes.

${ }^{9}$ In one-fifth of our country-year observations, our estimate of the expected rate of inflation is greater than the median wage increase, implying that "the lower tail" covers more than 50 percent of the observations. For these country-years, this measure of downward rigidity cannot be constructed.
} 
If everyone had exactly the same expected rate of inflation, and the distribution of wage changes in the absence of wage rigidity was symmetric, then the fraction of workers in the upper tail minus the fraction in the lower tail below the expected rate of inflation would equal the fraction of workers with real wage freezes. But even if our estimate of the expected rate of inflation coincides with the median of the expected rate of inflation for our observations, half of all wage changes will in fact be based on inflation expectations that are lower than our estimate. If these wage setters receive a wage change equal to their own expected rate of inflation, their wage change will be below our expected rate of inflation. Thus, even if downward real wage rigidity binds for these observations, they will still not be missing in the lower tail to the left of our estimated expected rate of inflation. Since half those with freezes will be missing from the lower tail, we multiply the missing observations in the lower tail by two.

To calculate the fraction of workers covered by downward real wage rigidity, we must divide the number of workers with real wage freezes by the number potentially affected, which is all workers who would have received a wage change below our estimate of the expected rate of inflation in the absence of downward real rigidity which we estimate as equal to the fraction of workers in the upper tail. Formally, we obtain

$$
r=f_{r} /\left(f_{r}+c_{r}\right)=2(u-l) / u,
$$

where $u$ is the fraction of observations in the upper tail above $m+\left(m-\pi^{e}\right) ; m$ is the median and $\pi^{e}$ is the expected rate of inflation; $l$ is the fraction of observations in the lower tail below $\pi^{e} ; f_{r}=2(u-l)$ is the fraction of workers for whom downward wage rigidity binds; and $f_{r}+c_{r}=u$ is thus our measure of real freezes plus real cuts. We construct $\pi^{e}$ as the predicted rate of inflation from a country-specific regression of annual rates of inflation on lagged inflation.

A large value for real rigidity $r$ may reflect phenomena other than downward real wage rigidity, because a concentration of wage changes at values other than the expected rate of inflation could affect it. For example, if government, business, and labor agree on a minimum wage increase meant to apply to all workers, our measure could show this as real rigidity even if the minimum wage increase allowed real growth or decline. In the interests of expositional brevity, we call $r$ "downward real rigidity," even though we recognize that the focal change could deviate from price inflation expectations.

It is worth noting that the concepts we attempt to measure here are quite different from the common conception of nominal and real wage rigidity as slow adjustment to nominal and real shocks. While downward nominal and downward real rigidity might be causes of slow adjustment, there could be other sources of slow adjustment. Moreover, remember that these measures of nominal and real rigidity do not show the actual percentage of workers experiencing nominal and real rigidity; rather they attempt to capture what share of workers relative to the 
group that might otherwise have experienced declining nominal or real wages, experiences wage rigidity instead.

As illustrations, we report these measures for the four distributions shown in Figure 1. The U.S. economy in 1987 shows high nominal rigidity, with $n=54$ percent, but no apparent real rigidity, with $r=-3$ percent. ${ }^{10}$ Finland's whitecollar employees in 1988 show low nominal rigidity at $n=18$ percent, but high real rigidity at $r=99$ percent. The United Kingdom in 1984 shows fairly high nominal and real rigidity, with $n=28$ percent and $r=30$ percent. Ireland in 1996 shows little of either rigidity, with nominal rigidity, $n,=3$ percent and real rigidity, $r,=1$ percent.

\section{Variation in our Rigidity Measures}

We now wish to explore whether wage rigidity differs across countries. We find considerable variation in the extent of both real and nominal rigidity across countries when we average across all datasets and time, as shown in Figure 3. Averaging across years and datasets within countries, estimates of the fraction of workers covered by downward nominal wage rigidity, $n$, averages 28 percent and ranges from 4 percent in Ireland to 58 percent in Portugal, while the comparable average for real rigidity, $r$, is 26 percent, with a range from 1 percent in the Netherlands to 68 percent in Sweden. The standard deviations of $n$ and $r$ across all our dataset-year observations are 13 and 22 percentage points, respectively. The differences across countries are statistically significant at any conventional level of significance. ${ }^{11}$

We compared our measures to those from two other cross-country studies that use different methodologies to estimate the average extent of downward nominal wage rigidity. Our country average estimates of downward nominal rigidity have correlation coefficients of 0.46 with 15 country estimates from Holden and Wulfsberg (2006, appendix table) and 0.45 with 11 country estimates from Knoppik and Beissinger (2005). We would not expect a perfect correlation because the estimates cover different time periods and diverge in data and technique. Thus, we consider the correspondence between these studies to be reasonably strong.

Do these differences in wage rigidity across countries reflect real differences in labor markets across the countries or do they reflect only differences in the way

\footnotetext{
${ }^{10}$ Even though we think of $r$ as the fraction of workers covered by downward real rigidity, our measure takes a negative value if the fraction of observations in the lower tail below the expected rate of inflation is greater than the fraction in the upper tail to which it is compared.

${ }^{11}$ Specifically, we regress these country-year measures on a set of country indicator variables and test their joint significance. For both downward nominal rigidity $(r)$ and downward real wage rigidity $(n)$, we easily reject the hypothesis that the extent of measured rigidity is constant across countries at any conventional level of significance. For downward real rigidity $(r), \mathrm{F}=7.63$; df(15, 257). For downward nominal wage rigidity $(n), \mathrm{F}=10.01 ; \mathrm{df}(15,344)$.
} 


\section{Figure 3}

\section{Real and Nominal Rigidity by Country \\ (fraction of workers potentially affected)}

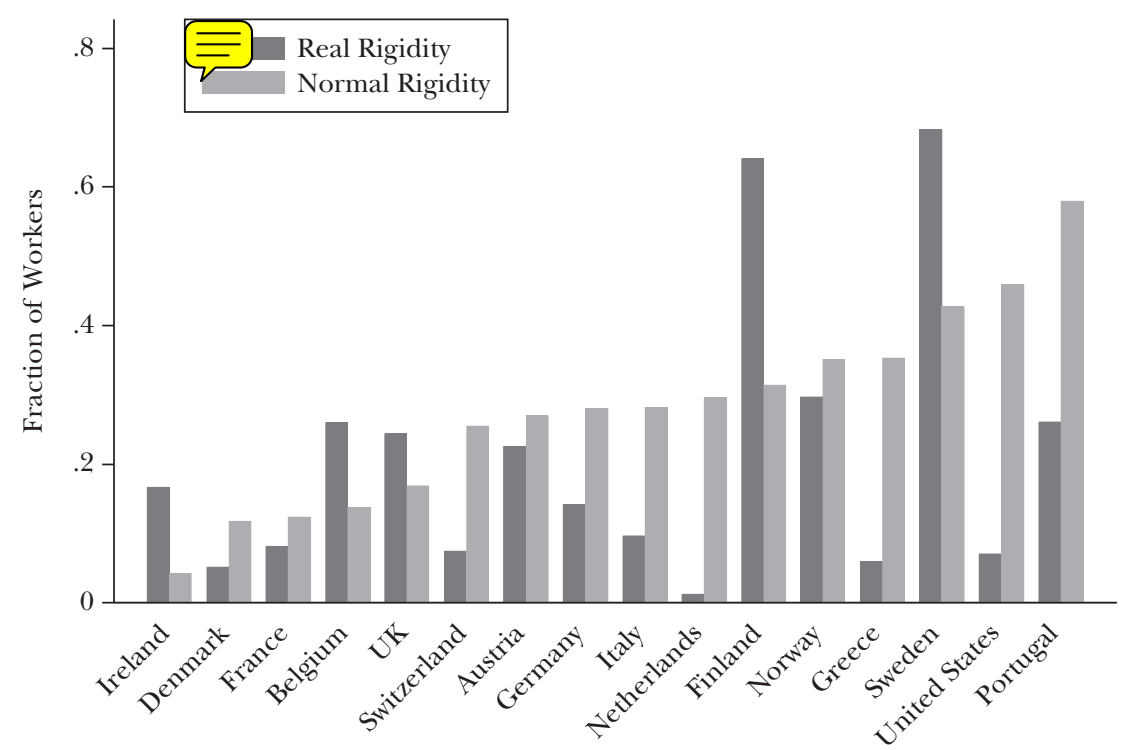

Note: The table shows the fraction of worker in each country potentially affected by downward real and nominal wage rigidity.

wages are reported, recorded, and computed in the different datasets? To find out, we run regressions with our measure of nominal rigidity $n$ and real rigidity $r$ as the dependent variables. For the explanatory variables, we first use indicator variables for a number of different dataset characteristics: whether we have hours information, whether the wage measure is based on total earnings or base wages, whether the wage measure is based on annual income, whether the data were collected with a labor market survey, and whether the data came from the European Community Household Panel. We also add our index of measurement error-the auto-covariance of wage changes-as an explanatory variable. Several of the dataset characteristics are statistically significant. In particular, there are positive and statistically significant coefficients on the auto-covariance of wage changes in both regressions, suggesting that measurement error biases both of our rigidity measures downward. However, even after adjusting for dataset characteristics, country differences in both downward nominal and downward real rigidity remain statistically significant at the 0.001 level. $^{12}$

\footnotetext{
${ }^{12}$ For downward real rigidity $(r), \mathrm{F}=2.24$ and $(\mathrm{df}=15,251)$. For downward nominal wage rigidity $(n)$, $\mathrm{F}=7.96$ and $(\mathrm{df}=15,338)$. We tested the validity and robustness of these country estimates in a number of ways laid out in full detail in Dickens et al. (2006). The two main changes were to incorporate corrections for measurement error and to estimate the size of rigidities by comparing true wage changes
} 
Since the cross-country differences in wage rigidity do not seem readily explainable by the characteristics of the data, we next examined the correlation of our rigidity measures with a number of measures of labor market institutions and other characteristics of the economy which might influence the functioning of the labor market. The variables we examined included two measures of strike activity; union density; union coverage; two indexes of the level at which bargaining takes place; two indexes of the degree of coordination in bargaining; a corporatism index combining level and coordination in bargaining; the fraction of part-time workers in the labor force; the fraction of temporary workers in the labor force; two measures of income distribution; six measures of the average tax wedge in compensation; four indices of employment protection legislation; two measures of the average replacement rates for unemployment benefits; duration of unemployment benefits; an indicator variable for the presence of any sort of institutional wage indexation; indices of the extent of active and passive labor market policies; two measures of the impact of minimum wages; a measure of the openness of the economy; and two indices of the extent of product market regulation. ${ }^{13}$

For each measure we correlated country averages for the variable with country averages for our rigidity measures and we also regressed our country-year estimates of our rigidity measures on the individual labor market variables and our dataset characteristic variables. Figure 4 shows scatterplots of the relationship between $n$ and $r$, and three of the many variables we examined-namely employment protection legislation, corporatism, and union density.

Of all the characteristics we examine, only the relationship between real rigidity and union density is statistically significant at the 0.05 level in both the country- and dataset-year-level regressions. There we find that increasing union density is associated with increasing real rigidity. It is plausible that collective bargaining would give more attention to real, as opposed to nominal, compensation because the participants may be more likely to understand the difference, hold expectations for the future inflation, and be more likely to be familiar with inflation

with the hypothetical wage change distribution that would prevail in the absence of rigidities. The differences across countries remain statistically significant.

${ }^{13}$ We drew upon six sources for these institutional variables: 1) Checchi and Lucifora (2002) provide an index of wage indexation (extended by the authors); measures of earnings inequality; measure of openness to international trade; index of overall product market regulation; and ratio of minimum to average wage. 2) Elmeskov, Martin, and Scarpetta (1998), including updates, where available, from OECD $(2004,2005)$, provide data on percentage of trade union coverage; percentage of trade union membership; wage bargaining centralization index; wage bargaining coordination index; average and marginal tax wedge measures; index of employment protection legislation on aggregate, regular, and temporary contracts; gross benefit replacement rate; ratio of minimum to median wage; index of overall product market regulation; and expenditure on active and passive labor market policies. 3) Eurostat's Labour Force Survey, available at $<$ http://epp.eurostat.ec.europa.eu $>$, provided data on percentage of part-time employment and percentage of temporary employment. 4) Golden, Lange, and Wallerstein (1999) provided data on bargaining level. 5) International Labour Organisation, at <http://www.ilo.org >, provided data on measures of strike activity. 6) Nickell and Nuziata (2000) provide an index of bargaining coordination; average tax wedge; index of employment protection legislation; average replacement rate; and duration of unemployment benefits. 


\section{Figure 4}

\section{Correlations of Institutional Variables with Rigidity Measures}

(Pearson's $\mathrm{r}$ is the correlation; significance levels in parentheses)
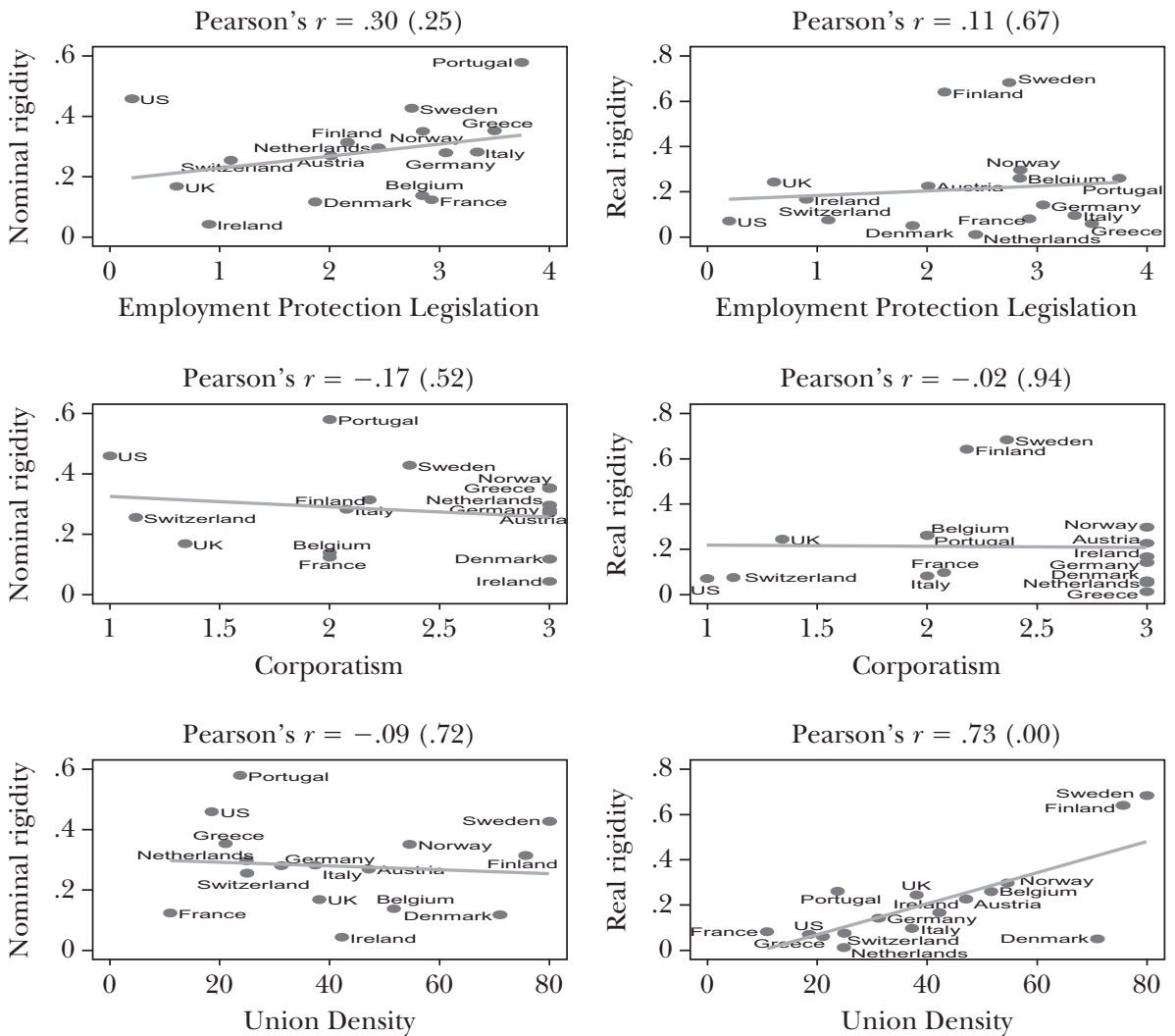

Sources: Aggregate Employment Protection Legislation: OECD (2004), Corporatism and Union Density: Elmeskov, Martin, and Scarpetta (1998).

Notes: Aggregate Employment Protection Legislation: Index of the strictness of employment protection legislation; categorical variable coded 0 to 6 , where 6 is most restrictive. Corporatism: Wage-bargaining corporatism index, summary measure of collective bargaining structures of centralization and coordination; categorical variable coded $1=$ low to $3=$ high. Union Density: The proportion of workers who are members of a trade union, in percent. Pearson's $r$ gives the correlations; significance levels in parentheses.

forecasts. Furthermore, unions might also have the bargaining power to ensure compensation for inflation in situations where nonunionized workers might have to accept constant nominal wages.

But even the connection between unions and wage rigidity, although it may seem obvious in theory, appears somewhat shakier in our data than one might expect. For example, if union density is a significant predictor of real wage rigidity, one might expect that bargaining coverage would also be positively related with real rigidity, but the correlation is only significant at the .10 level in a one-tailed-test in both specifications. 
When it comes to the effect of union density and coverage on nominal rigidity, the simple correlations of country averages are both negative, but neither is statistically significant. However, when we use annual observations, control for dataset characteristics, and use Huber-White standard errors clustered on country, the correlations become statistically significantly negative. We conjecture that by causing workers to focus on real rather than nominal values unions may reduce the importance of downward nominal wage rigidity.

We examined our estimates of downward real and downward nominal rigidity for evidence of time trends, and find no consistent evidence of changes over time for all countries combined. However, there are a few country-specific trends. Notably, there is some evidence that downward real rigidity in the United States in the 1970s virtually disappears in the 1980s, coincident with the decline in pattern bargaining by U.S. unions (Blanchflower and Freeman, 1992).

We also examined the relationship of wage rigidity to inflation. As explained earlier, our measures of the extent of nominal and real wage rigidity were constructed with the intention that they should not be much affected by inflation, and they are not. Our measures describe the likelihood that a worker facing the probability of stagnant or declining nominal wages receives a wage freeze. The fraction of workers actually affected by downward nominal wage rigidity is another matter; this fraction should rise as inflation falls, since the number of workers to whom firms would like to give pay cuts is larger when inflation is low. Indeed, we find that the fraction of workers with nominal wage freezes in any year declines by more than 1.4 percentage points for each percentage point increase in the median wage change. The coefficient hardly changes when we add controls for dataset characteristics and country indicator variables, and it gets larger when we add indicator variables for year.

\section{Conclusion}

With data from 15 European countries and the United States, we find that wage change distributions have a number of characteristics in common and some important differences. In all countries at nearly all times, the distribution of wage changes is notably nonnormal. The Weibull distribution provides a much better fit to the upper tail above the median. The lower tail of the wage distribution varies from country to country. Some countries show little downward rigidity in nominal or real wages, and in those cases the lower tail of the wage distribution takes on the Weibull form. Other countries show downward rigidity of nominal wages, but not real wages; downward rigidity of real wages, but not nominal wages; or even a fair degree of downward rigidity in both real and nominal wages.

We find substantial differences across the countries in our study in the extent of both nominal and real downward wage rigidity. Across countries, we estimate that an average of 28 percent of workers are covered by downward nominal rigidity, in the sense that 28 percent of the wage cuts that would have taken place under 
flexible wage setting are prevented by downward rigidity. Correspondingly, an average of 26 percent of workers are covered by downward real rigidity, in the sense that 26 percent of the real wage cuts that would have taken place under more flexible wage setting are prevented by downward rigidity. Measurement error appears to bias both measures downward, so the incidence of both nominal and real rigidities is probably higher. Nevertheless, these similar averages mask considerable variety: country averages for downward real wage rigidity range from 1 percent in the Netherlands to 68 percent in Sweden with a standard deviation across countries of 22 percentage points. For downward nominal wage rigidity, country averages for the fraction of workers covered range from 4 percent in Ireland to 58 percent in Portugal, with a standard deviation of 13 percentage points. Although differences in the nature of our data across countries certainly explain some of the cross-country variation of our rigidity measures, large differences remain even after we control for dataset characteristics.

Wage-setting behavior and wage rigidity have important implications for firm behavior, unemployment, macroeconomic stability, and other areas of economics; yet many questions remain to be answered about why these patterns occur. We have offered some hypotheses about the sort of wage-setting mechanisms that could underlie a Weibull distribution, but these explanations deserve further consideration and exploration. Although we examined many labor market and related economic variables that might plausibly help explain differences across countries in the extent of wage rigidity, the only solid connection we find is that union density has a robust positive association with downward real rigidity.

- This paper reports the results of the International Wage Flexibility Project. The International Wage Flexibility Project country team members are Cedric Audenis, Richard Barwell, Thomas Bauer, Petri Bockerman, Holger Bonin, Pierre Biscourp, Ana Rute Cardoso, Francesco Devicienti, Orrietta Dessy, John Ekberg, Tor Eriksson, Bruce Fallick, Ernst Fehr, Nathalie Fourcade, Seppo Laaksonen, Michael Lettau, Pedro Portugal, Jimmy Royer, Mickael Backman, Kjell Salvanes, Paolo Sestito, Alfred Stiglbauer, Uwe Sunde, Jari Vainiomaki, Marc van Audenrude, William Wascher, Rudolf Winter-Ebmer, Niels Westergaard-Nielson, and Josef Zuckerstaetter. We are grateful to the European Central Bank, IZA, Federal Reserve Bank of New York, and Volkswagen Foundation for their generous support. Philippe Moutot and Francesco Mongelli provided helpful guidance as our contacts at the ECB. The work of Julián Messina is partially supported by Research Grant SEJ2004-03276/ECON from the Spanish Ministry of Education and Science. The discussants and participants at the IWFP conference held in Frankfurt in June 2004 provided useful input that helped shape the project. Finally, Daniel Egel and Rebecca Vichniac wrote most of the programs used by the country teams and consulted extensively with them on the implementation of the IWFP protocol. Their contribution to the project goes well beyond what is normally acknowledged as excellent research assistance. The views expressed in this article are those of the authors and do not reflect the views of the Federal Reserve System, The European Central Bank, or any other organization with which authors or team members are affiliated. 


\section{References}

Akerlof, George A., William T. Dickens, and George L. Perry. 1996. "The Macroeconomics of Low Inflation." Brookings Papers on Economic Activity, no. 1. pp. 1-75.

Altonji, Joseph G., and Paul J. Devereux. 2000. "The Extent and Consequences of Downward Nominal Wage Rigidity." In Worker WellBeing, ed. S. Polachek, 383-431. Research in Labour Economics, vol.19. New York: Elsevier.

Blanchflower, David, and Richard Freeman. 1992. "Unionism in the U.S. and in Other Advanced OECD Countries." Industrial Relations, 31(1): 56-79.

Camba-Mendez, Gonzalo, Juan Angel Garcia, Diego Rodrígquez Palenzuela. 2003. "Relevant Economic Issues Concerning the Optimal Rate of Inflation." In Background Studies for the ECB's Evaluation of its Monetary Policy Strategy, ed. Otmar Issing, 91-126. European Central Bank.

Checchi, Daniele, and Claudio Lucifora. 2002. "Unions and Labour Market Institutions in Europe." Economic Policy, 17(35): 362-401

Dickens, William T., Lorenz Goette, Erica L. Groshen, Steinar Holden, Julian Messina, Mark E. Schweitzer, Jarkko Turunen, and Melanie Ward. 2006. "The Interaction of Labor Markets and Inflation: Micro Evidence from the International Wage Flexibility Project." http://www. brook.edu/es/research/projects/iwfp_jep.pdf.

Elmeskov, Jorgen, John P. Martin, and Stefano Scarpetta. 1998. "Key Lessons for Labour Market Reforms: Evidence from OCED Countries' Experiences." Swedish Economic Policy Review, 5(2): 205-252

Golden, Miriam, Peter Lange, and Michael Wallerstein. 1999. "Postwar Trade Union Organization and Industrial Relations in Twelve Countries." In Continuity and Change in Contem- porary Capitalism, 194-230. New York: Cambridge University Press.

Holden, Steinar. 2004. "Wage Formation under Low Inflation." In Collective Bargaining and Wage Formation-Challenges for an European Labour Market, ed. H. Piekkola and K. Snellman, 39-58. Springer.

Holden, Steinar, and Fredrik Wulfsberg. 2006. Downward Nominal Wage Rigidity in the OECD. http://folk.uio.no/sholden/\#wp.

Knoppik, Christoph, and Thomas Beissinger. 2005. "Downward Nominal Wage Rigidity in Europe: An Analysis of European Micro Data from the ECHP 1994-2001.” IZA Discussion Papers 1492, from the Institute for the Study of Labor (IZA).

Lebow, David E., Raven E. Saks, Beth Anne Wilson. 2003. "Downward Nominal Wage Rigidity: Evidence from the Employment Cost Index." Advances in Macroeconomics, 3(1): Article 2.

Nickell, Stephen J., and Luca Nuziata. 2000. "Employment Patterns in OECD Countries," Center for Economic Performance Discussion Paper 448.

Nickell, Stephen J. and Glenda Quintini. 2003. "Nominal Wage Rigidity and the Rate of Inflation." Economic Journal, 113(490): 762-781.

Organisation for Economic Co-operation and Development. 2004. "Wage Setting Institutions and Outcomes." In OECD Employment Outlook, chap. 3. OECD.

Organisation for Economic Co-operation and Development. 2005. OECD Employment Outlook. OECD.

Rosen, Sherwin. 1986. "Prizes and Incentives in Elimination Tournaments," American Economic Review, 76(4): 701-15.

Smith, Jennifer C. 2000. "Nominal Wage Rigidity in the United Kingdom," Economic Journal, March, 110(462): C176-95. 


\section{This article has been cited by:}

1. John C. Driscoll, Steinar Holden. 2014. Behavioral economics and macroeconomic models. Journal of Macroeconomics 41, 133-147. [CrossRef]

2. Jorge De la Roca. 2014. Wage cyclicality: Evidence from Spain using social security data. SERIEs 5, 173-195. [CrossRef]

3. Emiliano Santoro, Ivan Petrella, Damjan Pfajfar, Edoardo Gaffeo. 2014. Loss aversion and the asymmetric transmission of monetary policy. Journal of Monetary Economics . [CrossRef]

4. Edward F. Buffie. 2014. The Taylor principle fights back, Part II. Journal of Economic Dynamics and Control . [CrossRef]

5. Stefan Reitz, Ulf D. Slopek. 2014. FIXING THE PHILLIPS CURVE: THE CASE OF DOWNWARD NOMINAL WAGE RIGIDITY IN THE US. International Journal of Finance \& Economics 19:2, 122-131. [CrossRef]

6. Alessandro Barattieri, Susanto Basu, Peter Gottschalk. 2014. Some Evidence on the Importance of Sticky Wages†. American Economic Journal: Macroeconomics 6:1, 70-101. [Abstract] [View PDF article] [PDF with links]

7. Julián Messina, Anna Sanz-de-Galdeano. 2014. Wage Rigidity and Disinflation in Emerging Countries $\dagger$. American Economic Journal: Macroeconomics 6:1, 102-133. [Abstract] [View PDF article] [PDF with links]

8. Nizar Jouini, Nooman Rebei. 2014. The welfare implications of services liberalization in a developing country. Journal of Development Economics 106, 1-14. [CrossRef]

9. B. Annicchiarico, A. Pelloni. 2014. Productivity growth and volatility: how important are wage and price rigidities?. Oxford Economic Papers 66:1, 306-324. [CrossRef]

10. Sónia Cabral, Cláudia Duarte. 2014. Nominal and real wage rigidity: Does nationality matter?. IZA Journal of European Labor Studies 3, 13. [CrossRef]

11. Edward F. Buffie. 2013. The Taylor principle fights back, Part I. Journal of Economic Dynamics and Control 37:12, 2771-2795. [CrossRef]

12. Sanvi Avouyi-Dovi, Denis Fougère, Erwan Gautier. 2013. Wage Rigidity, Collective Bargaining, and the Minimum Wage: Evidence from French Agreement Data. Review of Economics and Statistics 95:4, 1337-1351. [CrossRef]

13. Hyuk Jae Rhee, Jeongseok Song. 2013. Real wage rigidities and optimal monetary policy in a small open economy. Journal of Macroeconomics 37, 110-127. [CrossRef]

14. Renato Faccini, Stephen Millard, Francesco Zanetti. 2013. Wage Rigidities in an Estimated Dynamic, Stochastic, General Equilibrium Model of the UK Labour Market. The Manchester School 81, 66-99. [CrossRef]

15. Stephanie Schmitt-Grohé,, Martín Uribe. 2013. Downward Nominal Wage Rigidity and the Case for Temporary Inflation in the Eurozone. Journal of Economic Perspectives 27:3, 193-212. [Abstract] [View PDF article] [PDF with links]

16. Mirko Abbritti, Stephan Fahr. 2013. Downward wage rigidity and business cycle asymmetries. Journal of Monetary Economics . [CrossRef]

17. Daniel A. Dias, Carlos Robalo Marques, Fernando Martins. 2013. Wage rigidity and employment adjustment at the firm level: Evidence from survey data. Labour Economics 23, 40-49. [CrossRef]

18. Salem Abo-Zaid. 2013. Optimal monetary policy and downward nominal wage rigidity in frictional labor markets. Journal of Economic Dynamics and Control 37:1, 345-364. [CrossRef] 
19. Emi Nakamura, Jón Steinsson. 2013. Price Rigidity: Microeconomic Evidence and Macroeconomic Implications. Annual Review of Economics 5:1, 133-163. [CrossRef]

20. Nizar Jouini, Nooman Rebei. 2013. The Welfare Implications of Services Liberalization in a Developing Country: Evidence from Tunisia. IMF Working Papers 13, 1. [CrossRef]

21. Lucian A. Taylor. 2012. CEO wage dynamics: Estimates from a learning model. Journal of Financial Economics . [CrossRef]

22. O. Coibion, Y. Gorodnichenko, J. Wieland. 2012. The Optimal Inflation Rate in New Keynesian Models: Should Central Banks Raise Their Inflation Targets in Light of the Zero Lower Bound?. The Review of Economic Studies 79:4, 1371-1406. [CrossRef]

23. Jan Babecký, Philip Du Caju, Theodora Kosma, Martina Lawless, Julián Messina, Tairi Rõõm. 2012. How do European firms adjust their labour costs when nominal wages are rigid?. Labour Economics 19:5, 792-801. [CrossRef]

24. Hervé Le Bihan,, Jérémi Montornès,, Thomas Heckel. 2012. Sticky Wages: Evidence from Quarterly Microeconomic Data. American Economic Journal: Macroeconomics 4:3, 1-32. [Abstract] [View PDF article] [PDF with links]

25. Yuriy Gorodnichenko,, Enrique G. Mendoza,, Linda L. Tesar. 2012. The Finnish Great Depression: From Russia with Love. American Economic Review 102:4, 1619-1643. [Abstract] [View PDF article] [PDF with links]

26. Markus Knell, Alfred Stiglbauer. 2012. REFERENCE NORMS, STAGGERED WAGES, AND WAGE LEADERSHIP: THEORETICAL IMPLICATIONS AND EMPIRICAL EVIDENCE*. International Economic Review 53:2, 569-592. [CrossRef]

27. Heiko Stüber, Thomas Beissinger. 2012. Does downward nominal wage rigidity dampen wage increases?. European Economic Review 56:4, 870-887. [CrossRef]

28. P. Du Caju, C. Fuss, L. Wintr. 2012. Sectoral differences in downward real wage rigidity: workforce composition, institutions, technology and competition. Journal for Labour Market Research 45:1, 7-22. [CrossRef]

29. Juan A. Garcia-Cebro, Ramón Varela-Santamaría. 2011. The international transmission of monetary shocks across developed countries: The role of imported raw materials. Journal of International Money and Finance . [CrossRef]

30. Jinill Kim, Francisco J. Ruge-Murcia. 2011. Monetary policy when wages are downwardly rigid: Friedman meets Tobin. Journal of Economic Dynamics and Control . [CrossRef]

31. Marius Brülhart, Céline Carrère, Federico Trionfetti. 2011. How wages and employment adjust to trade liberalization: Quasi-experimental evidence from Austria. Journal of International Economics . [CrossRef]

32. BARBARA ANNICCHIARICO, LUISA CORRADO, ALESSANDRA PELLONI. 2011. LONGTERM GROWTH AND SHORT-TERM VOLATILITY: THE LABOUR MARKET NEXUS*. The Manchester School 79, 646-672. [CrossRef]

33. Carlo Altavilla, Concetto Paolo Vinci. 2011. NON-LINEAR DYNAMICS OF REAL WAGES OVER THE BUSINESS CYCLE. Journal of Applied Economics 14:1, 81-99. [CrossRef]

34. Andrew Seltzer, André Sammartino. 2011. Nominal wage rigidity prior to compulsory arbitration: evidence from the Victorian Railways, 1902-1921. Cliometrica 5:1, 53-78. [CrossRef]

35. Lenard Lieb. 2011. Taking Real Wage Rigidities Seriously: Implications for Optimal Policy Design in a Currency Union. International Economic Journal 1-32. [CrossRef]

36. Stephan Fahr, Frank Smets. 2010. Downward Wage Rigidities and Optimal Monetary Policy in a Monetary Union*. Scandinavian Journal of Economics 112:4, 812-840. [CrossRef] 
37. Jan Babecký, Philip Du Caju, Theodora Kosma, Martina Lawless, Julián Messina, Tairi Rõõm. 2010. Downward Nominal and Real Wage Rigidity: Survey Evidence from European Firms*. Scandinavian Journal of Economics 112:4, 884-910. [CrossRef]

38. Grégory Walque, Michael Krause, Stephen Millard, Juan Jimeno, Hervé Le Bihan, Frank Smets. 2010. SOME MACROECONOMIC AND MONETARY POLICY IMPLICATIONS OF NEW MICRO EVIDENCE ON WAGE DYNAMICS. Journal of the European Economic Association 8:2-3, 506-513. [CrossRef]

39. Silvia Fabiani, Claudia Kwapil, Tairi Rõõm, Kamil Galuscak, Ana Lamo. 2010. WAGE RIGIDITIES AND LABOR MARKET ADJUSTMENT IN EUROPE. Journal of the European Economic Association 8:2-3, 497-505. [CrossRef]

40. Julián Messina, Cláudia Filipa Duarte, Mario Izquierdo, Philip Caju, Niels Lynggård Hansen. 2010. THE INCIDENCE OF NOMINAL AND REAL WAGE RIGIDITY: AN INDIVIDUAL-BASED SECTORAL APPROACH. Journal of the European Economic Association 8:2-3, 487-496. [CrossRef]

41. Ernst Fehr, Lorenz Goette, Christian Zehnder. 2009. A Behavioral Account of the Labor Market: The Role of Fairness Concerns. Annual Review of Economics 1:1, 355-384. [CrossRef]

42. Petri Böckerman, Roope Uusitalo. 2009. Minimum Wages and Youth Employment: Evidence from the Finnish Retail Trade Sector. British Journal of Industrial Relations 47:2, 388-405. [CrossRef]

43. Steinar Holden, Fredrik Wulfsberg. 2009. How strong is the macroeconomic case for downward real wage rigidity?. Journal of Monetary Economics 56:4, 605-615. [CrossRef]

44. Ernst Fehr, Martin Brown, Christian Zehnder. 2009. On Reputation: A Microfoundation of Contract Enforcement and Price Rigidity. The Economic Journal 119:536, 333-353. [CrossRef]

45. Luca Antonio Ricci, Pierpaolo Benigno. 2009. The Inflation-Unemployment Trade-Off At Low Inflation. IMF Working Papers 09, 1. [CrossRef]

46. CARSTEN HEFEKER. 2008. UNCERTAINTY AND WAGE SETTING IN A MONETARY UNION. The Manchester School 76:4, 391-404. [CrossRef]

47. T. Kyyra, M. Maliranta. 2008. The micro-level dynamics of declining labour share: lessons from the Finnish great leap. Industrial and Corporate Change 17:6, 1147-1172. [CrossRef]

48. Marvin Goodfriend. 2007. How the World Achieved Consensus on Monetary Policy. Journal of Economic Perspectives 21:4, 47-68. [Abstract] [View PDF article] [PDF with links] 